In August, 1878, when the rate from Chicago to Council Bluffs was 26 cents per 100 pounds, W. J. Young \& Company received a new rate of 17 cents. The normal limit per car became 24,000 pounds, and the maximum 26,000. ${ }^{50}$ The railroad continued to charge what the traffic would bear, but no more, and allowed Young to continue his pursuit of the western trade. The Clinton lumber man's correspondence with the railroad over loading weights was as extensive as his letters about rates. In a sense, railroad rates and loading weights were synonymous terms. An advantage in one could easily be offset by a disadvantage in the other. Finally, an advantage or disadvantage with the railroad could determine success or failure for an entrepreneur in lumber marketing.

${ }^{50}$ George W. Forrest, Clinton, Ia., to Vigo Badollet, Omaha, Neb. Aug. 12, 1878, LPB 55, p. 249.

\title{
TELEPHONE EXHIBIT ADDED TO MUSEUM
}

One of the most exciting exhibits recently added to the State Historical Museum, Des Moines, is a telephone collection which covers the entire history of the telephone, from a replica of the original instrument used by Alexander Graham Bell in 1875 to the modern "touchtone" telephones and a model of Telstar, the satellite used to relay telephone messages.

Bell's first telephone was a crude device which transmitted the human voice, but not in a recognizable manner. After some perfection of his first apparatus, Bell patented his telephone on March 7, 1876, and a few days later the first complete and understandable sentence was transmitted. At this time, the telephone was generally scoffed at as no more than a scientific toy; however, Bell envisioned a great future of usefulness for his invention.

Once the public recognized the use and effectiveness of the telephone, its popularity grew. Two of the early telephones used in Iowa, certainly the first telephones in use in 
Des Moines, were on a line connecting F. M. Hubbell's office with his home. One of these telephones, dating 1878, is included in the Museum exhibit. In 1900, Davenport reported 96 telephones connected with a central office. Earlier that year, Cedar Rapids counted 29 telephone subscribers and, a short while later, a line connecting Cedar Rapids and Marion, Iowa, was completed. This line had 25 subscribers.

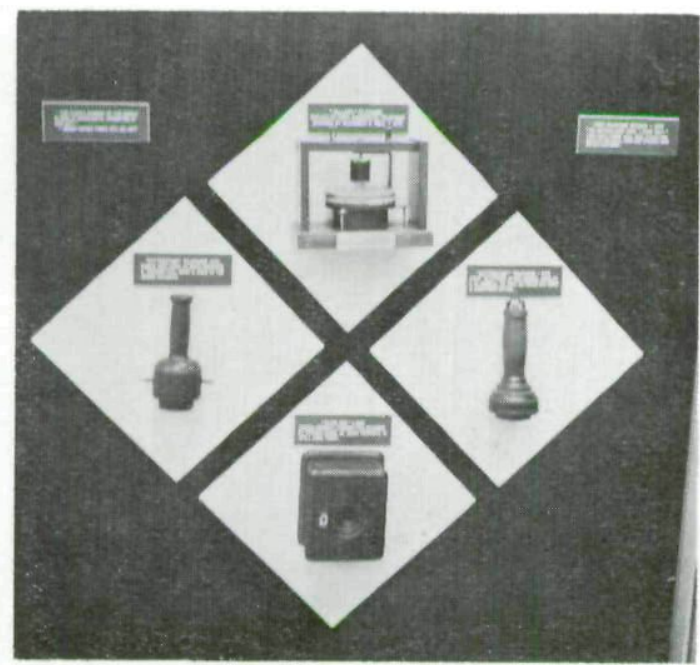

Pboto by Jobn Pbipps

\section{Early Telephone Equipment; Telephone on Right was the First Telephone in Des Moines, used by F. M. Hubbell.}

Although the telephone was, at this time, still a novelty which was far from perfected, telephone lines were no longer limited within towns and distance-lines were being conceived and laid.

The telephone collection, located on the second floor of the Museum, contains many of the early phones used in Iowa. Many of you can probably remember the old "crank" phones and those without dials into which you gave the operator the number you were calling, just as your children will someday remember the "old black dial phones" now rapidly being replaced by the colorful "touchtone" telephones. But these are 
just a few of the advancements of the telephone, as evidenced by the exhibit which includes an 1895 switchboard previously used in Viola, Iowa, until 1964; a number of wall phones dating from around the turn of the century; two Des Moines pay phones dating 1904 and 1909; a central office ringing machine from 1915; a collection of insulators; and many other telephones and equipment from early periods to the present.

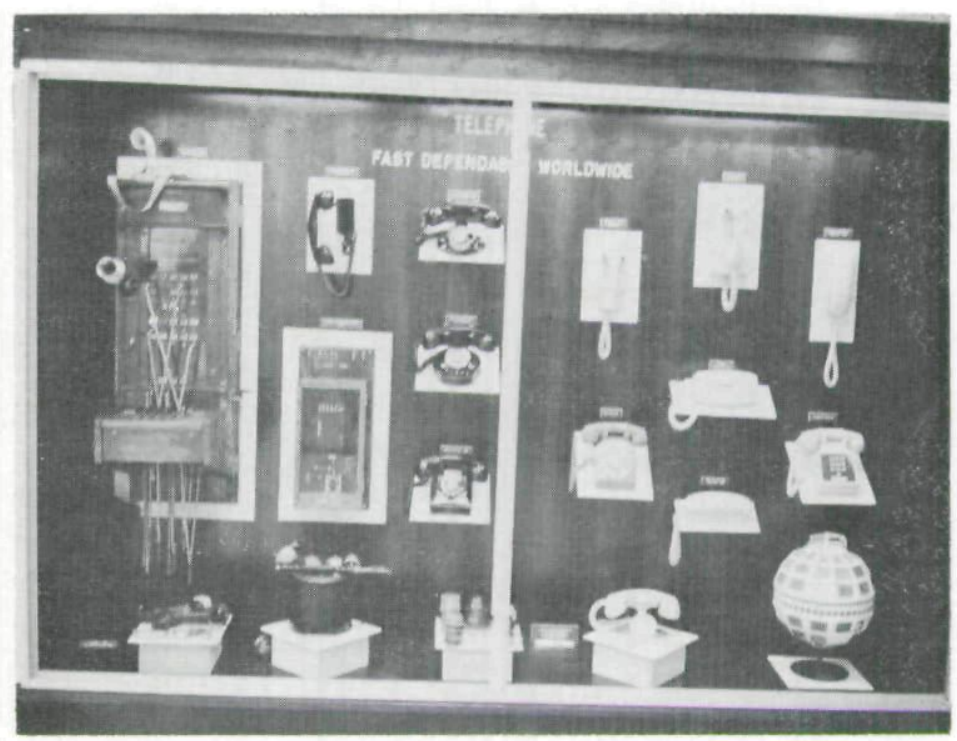

Pboto by Jobn Pbipps

The Switchboard to the Far Left Was Used in Viola from 1895 to 1964; To the Right Are the Latest "Touchtone" Telephones and Right, Bottom, is a Model of Telstar.

In viewing the exhibit and noting the many improvements in the style of the telephone and the advances in telephone equipment, one must also consider the many technical refinements made. Early distance lines had a limit of commercial service of 50 to 75 miles and calls of a longer distance had to be repeated by an operator at some switching point: Also, as these lines were grounded, they were subject to much cross talk and electrical interference. According to an article by Charles C. Deering, published in the April, 1942, Annals of 
Iowa, "One of these grounded toll lines from Boone to Des Moines paralleled for some distance the trolley line running to Valley Junction (now West Des Moines). Users of this toll line alleged that they could hear the conductor on the street car ring up fares." Not only were the early lines "noisy" but many of the lines were not connected thus there was a very limited sphere of communication. Today, one can converse via telephone with a friend in New York or California as clearly and easily as with a person just down the street.

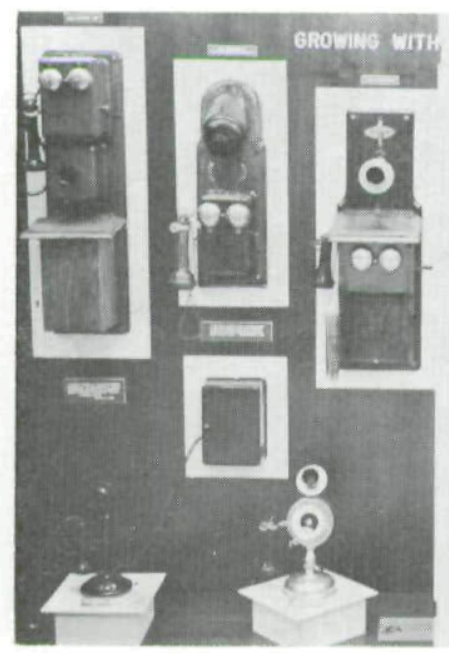

Telephone Exhibit, Second Floor; the Second Telephone from Left, Bottom, Was First Dial Phone in lowa.

Mr. John Phipps, Museum Director, and Mr. Fred Voitel, Administrative Assistant, were largely responsible for this fine exhibit. These two employees of the State Department of History and Archives, spent many long evenings and weekends planning, collecting and designing this telephone display and their work is certainly visible in the quality of the exhibit.

The Hawkeye Chapter of the Telephone Pioneers of America and the Northwestern Bell Telephone Company donated most of the equipment to the Museum and much thanks should be given them for their contribution. 
Copyright of Annals of Iowa is the property of State of Iowa, by \& through the State Historical Society of Iowa and its content may not be copied or emailed to multiple sites or posted to a listserv without the copyright holder's express written permission. However, users may print, download, or email articles for individual use. 